\author{
PROCEEDINGS OF THE NUTRITION SOCIETY \\ A Scientific Meeting was held at Regent's College, London on 2/3 December 1992
}

\title{
The Sir David Cuthbertson Medal Lecture 1992
}

\section{The immunological and metabolic effects of L-arginine in human cancer}

\author{
BY KENNETH G. M. PARK \\ The Department of Surgery, Aberdeen University, Foresterhill, Aberdeen AB9 2ZD \\ and The Rowett Research Institute, Bucksburn, Aberdeen AB2 9SB
}

It is both a great pleasure and an honour to be able to deliver this third Cuthbertson lecture, in memory of course of Sir David Cuthbertson who was, very much, the founding father of clinical metabolism. The work which I will describe in the present lecture was performed both at the Rowett Research Institute in Aberdeen and at the University Department of Surgery, also in Aberdeen. Cuthbertson had close connections with Aberdeen and was a former director of the Rowett Research Institute, 22 years previously, a post which he held from 1945 to 1965 . This was obviously before my time in Aberdeen and in fact my only encounter with Sir David was as a teenager, when he threw me off Royal Troon golf course.

In Aberdeen my function was rather like that of a cytokine, linking the metabolic work at the Rowett with the immunological work at the Department of Surgery, in looking at the effects of nutrition on cancer growth and metabolism.

\section{BACKGROUND}

The introduction of modern enteral and parenteral feeding regimens into clinical practice has meant that it is now possible to provide nutritional support to patients in a wide variety of clinical settings. In surgical practise the consequences of malnutrition (both obesity and undernutrition) are only too familiar to most clinicians. For example, many authors have reported diminished immunity, poor wound healing and reduced voluntary muscle activity in undernourished patients (Von Meyenfeldt et al. 1988; Windsor \& Hill, 1988; Wan et al. 1989). Studley (1936) first showed this to represent a significant risk to the surgical patient, and since then many other authors have confirmed the relationship between undernutrition and increased surgical morbidity, and even mortality (Conti et al. 1977; Muller et al. 1986; Detsky et al. 1987). Despite these observations it is not at all clear whether pre- and/or peri-operative nutrition can reverse malnutrition and reduce morbidity in such patients (Veterans Affairs Total Parenteral Nutrition Cooperative Study Group, 1991). There is even more conjecture regarding the value of nutritional support in malnourished cancer patients. A number of prospective controlled trials have been conducted (Table 1).

Care must be exercised in evaluating these trials. Comparisons are frequently made between groups containing both malnourished and well-nourished patients, assuming 
Table 1. Summary of the results of the trials of preoperative nutritional support in patients with cancer

\begin{tabular}{|c|c|c|c|c|c|c|}
\hline \multirow[b]{2}{*}{ Source } & \multicolumn{2}{|c|}{ No. in each group } & \multicolumn{2}{|c|}{ Mortality } & \multicolumn{2}{|c|}{ Morbidity } \\
\hline & Supplement & $\begin{array}{c}\text { No } \\
\text { supplement }\end{array}$ & Supplement & $\begin{array}{c}\text { No } \\
\text { supplement }\end{array}$ & Supplement & $\begin{array}{c}\text { No } \\
\text { supplement }\end{array}$ \\
\hline Holter \& Fisher (1977) & 30 & 26 & 2 & 2 & 11 & 11 \\
\hline Moghissi et al. (1977) & 10 & 5 & - & - & 0 & 1 \\
\hline Heatley et al. (1979) & 38 & 36 & 6 & 8 & 5 & 14 \\
\hline Sako et al. (1981) & 35 & 33 & 3 & 0 & 15 & 18 \\
\hline Thompson et al. (1981) & 12 & 9 & 0 & 0 & 5 & 3 \\
\hline Muller et al. (1982) & 66 & 59 & 3 & 11 & 11 & 19 \\
\hline Jensen (1985) & 10 & 10 & $*$ & $*$ & 1 & 6 \\
\hline
\end{tabular}

* Not reported.

that nutrition will be equally beneficial to both groups. This is clearly not the case as was shown recently in a large multi-centre trial; the value of nutritional support is dependent upon the level of nutritional impairment (Veterans Affairs Total Parenteral Nutrition Cooperative Study Group, 1991). Patients who are not undernourished will be subjected to the potential risks of nutritional therapy without any of the potential benefits. Of the seven trials reported, only five reported on the hospital mortality in their patients. The results were statistically significant only in the study of Muller et al. (1982), but the numbers of patients included in each arm of the remaining trials were insufficient to be confident that a therapeutic response had not been missed. An overview of all trials can be obtained by combining the results and calculating an odds ratio for the risk of death in all the 'fed' groups (i.e. those receiving supplements) compared with the control groups who received no supplement. From the trials reported in Table 1 the calculated odds ratio for mortality is 1.08 ; this is not significantly different from 1.00 , which would indicate that there was no clear benefit with regards to mortality in providing perioperative nutrition in cancer patients.

A possible explanation of these findings is that nutritional support may actually enhance tumour growth. Studies have been difficult to perform in man, but using techniques such as ultrasound and conventional radiology to measure tumours it has not been possible to demonstrate any effects of feeding on tumour growth (Nixon et al. 1981; Von Meyenfeldt et al. 1988). Based on such findings some reviewers have suggested that tumours are autologous and do not respond to the provision of nutrients (Douglas \& Shaw, 1990). Animal studies, however, have demonstrated that there does appear to be a stimulation in tumour growth during feeding (Popp et al. 1983; Torosian et al. 1984; King et al. 1985). Although animal tumour models are often a poor representation of human cancers, it is possible that the methods used to measure tumour growth in man are insufficiently sensitive to detect any alteration in tumour size.

\section{THE EFFECT OF FEEDING ON TUMOUR GROWTH}

A more sensitive measure of tumour growth may be to measure its rate of protein synthesis, as the growth of malignant cells in vitro has been demonstrated to be primarily 


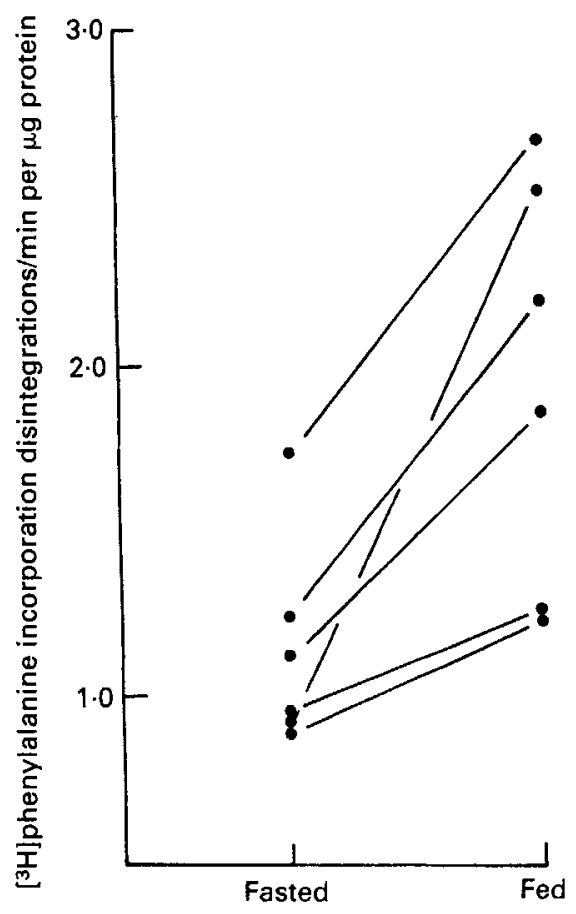

Fig. 1. Phenylalanine incorporation into tumour cells incubated in a medium enriched with 'fed' or 'fasted' serum. Each pair of linked points represents cells from one patient, incubated in that patient's own serum, collected in the fed or fasted state.

determined by the rate of protein synthesis (Lockwood et al. 1982; Baccino et al. 1984; McNurlan \& Clemens, 1986). Heys et al. (1991) used such a technique in vivo to determine the effect of parenteral nutrition on colorectal cancers. It was found that the rate of protein synthesis in the tumours of patients who were fasted was 21 (range 15-35) $\% / \mathrm{d}$ compared with 38 (range $28-61$ ) \%/d in a group of patients given $24 \mathrm{~h}$ of parenteral feeding. These results show that tumours certainly respond to the provision of nutrients. However, tumours are composed of a heterogeneous population of cells including cancer cells, stromal tissue cells, lymphocytes and macrophages. The consequences of an increased rate of tumour protein synthesis due to a stimulation of lymphoreticular cells are very different from a stimulation of the cancer cells themselves resulting in a stimulation of tumour protein synthesis. To determine the direct effects of feeding on cancer cells, I studied a group of six patients with histologically proven colorectal cancer. Each of these patients received an identical feeding regimen to the previous study (Heys et al. 1991). Before starting feeding and after $24 \mathrm{~h}$ of feeding blood samples were obtained for 'fasted' and 'fed' serum. The tumours were obtained at the time of surgery and by a mixture of mechanical and enzymic digestion a suspension of cancer cells was obtained (Kuppner et al. 1987). These cells were incubated in a medium enriched with serum from the same patient taken in either the fed or fasted state and the rate of cellular protein synthesis was determined by the incorporation of $\left[{ }^{3} \mathrm{H}\right]$ phenylalanine into the cancer cells. The results are expressed as disintegrations/min (dpm) per $\mu$ g protein (Fig. 1). In each case there was an increase in the rate of $\left[{ }^{3} \mathrm{H}\right]$ phenylalanine uptake into the 
tumour cells when incubated in the 'fed' serum, the mean increase being $78.5 \%$. The difference between the fed and fasted groups was significant at the $P<0.02$ level (paired $t$ test on log transformed data).

These experiments did appear to show that human cancers, in this case colorectal cancers, respond to the provision of nutrients. It was decided, therefore, to look in more detail at potential nutrients which may preferentially enhance aspects of the host defences without 'feeding' the tumour. The potential benefit of the basic amino acid, arginine, as a nutrient of this type has been suggested by its ability to reduce the growth and spread of tumours in experimental animals (Barbul, 1986). These effects appear to be as a consequence of the immune stimulatory effects of arginine in these animals (Barbul et al. 1977, 1980; Siato et al. 1987; Reynolds et al. 1988a). Similarly in man arginine has been demonstrated to enhance a number of immunological mechanisms (Barbul et al. 1981; Daly et al. 1990). In particular, arginine enhances the response of lymphocytes to polyclonal mitogens in normal volunteers. But does it have the same effect in cancer patients? Furthermore, the responses of lymphocytes to polyclonal mitogens are rather non-specific, can arginine, therefore, enhance the specific antitumour host defences?

\section{IMMUNOLOGICAL EFFECTS OF L-ARGININE}

Lymphocytes were obtained from the peripheral blood of six healthy volunteers and six patients with breast cancer and frozen in liquid $\mathrm{N}_{2}$. Each subject was then given $30 \mathrm{~g}$ L-arginine to take orally on each of the following $3 \mathrm{~d}$. On the fourth day a further blood sample was obtained and the lymphocytes separated on Ficol Hypaque gradients as described previously. The lymphocytes were again preserved in liquid $\mathrm{N}_{2}$. After thawing the lymphocytes were incubated with phytohaemagglutinin (PHA), concanavalin A (Con A) or pokeweed mitogen (PWM) for $48 \mathrm{~h}$ before being pulsed with $\left[{ }^{3} \mathrm{H}\right]$ thymidine and harvested onto glass-fibre discs. In each case the incorporation of the tritiated thymidine into the lymphocytes was determined by measuring radioactivity with a liquid-scintillation counter. The incorporation was determined over a range of concentrations of each mitogen and compared with controls in which lymphocytes were incubated in medium alone before pulsing with $\left[{ }^{3} \mathrm{H}\right]$ thymidine. The results were expressed as stimulation indices in which the maximum thymidine incorporation was compared with the incorporation in the control medium. Fig. 2 shows the before and after arginine transformation assays for one volunteer with PHA (a), PWM (b) and (c) ConA. The responses were similar in each volunteer. Fig. 3(a) shows the stimulation indices in each of the volunteers before and after arginine for PHA stimulation; the pre-arginine stimulation index was a median of 32 (range 16-41) and after arginine a median of 61 (range 31-93). These results confirm the similar findings of Barbul (1986) and others that arginine can enhance the proliferative response of lymphocytes in healthy individuals. In the patients with breast cancer the response to PHA was most marked. The pre-arginine stimulation index was 32 (range 10-30) and this was increased to a median of 43 (range 20-71) following arginine (Fig. 3(b)). This experiment has since been repeated by Brittenden et al. (1992), in our laboratory, for a larger group of patients with breast cancer and their findings confirm the stimulatory effect of arginine in such patients. 

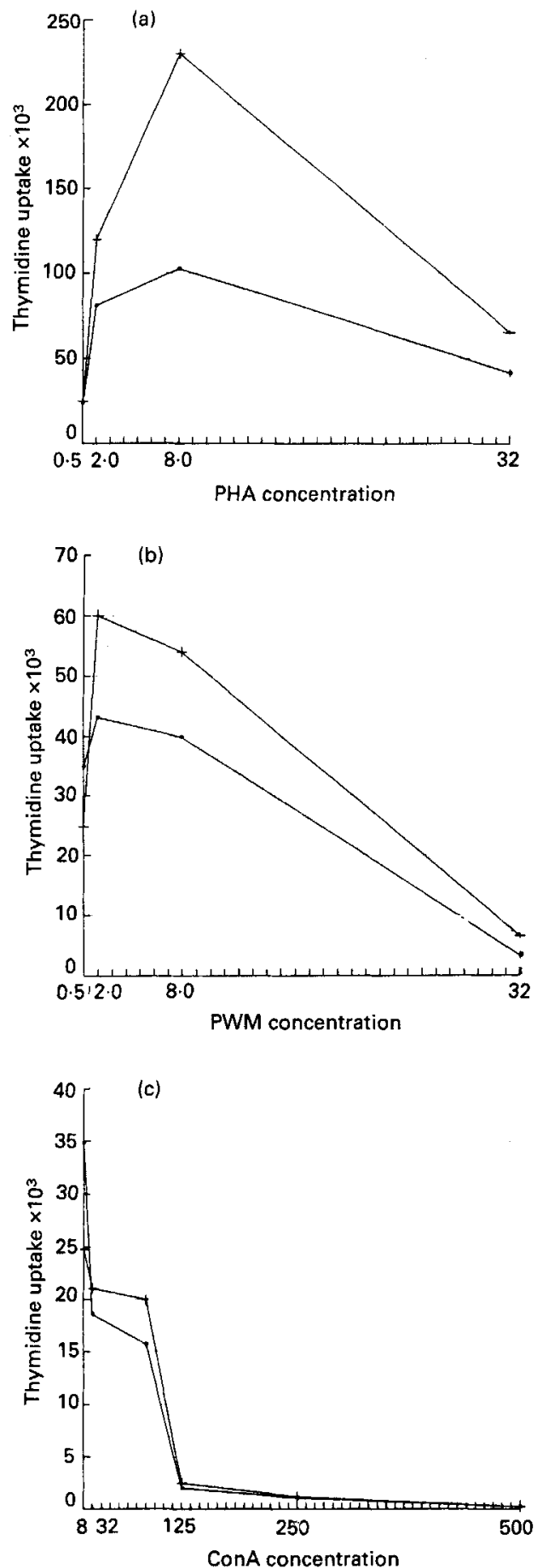

Fig. 2. Thymidine uptake of peripheral blood lymphocytes stimulated with: (a) phytohaemagglutinin (PHA), (b) pokeweed mitogen (PWM) or (c) concanavalin A (ConA) before $(\bullet)$ and after $(+)$ an oral dose of arginine $(30 \mathrm{~g} / \mathrm{d}$ for $3 \mathrm{~d})$. 
(a) Volunteers

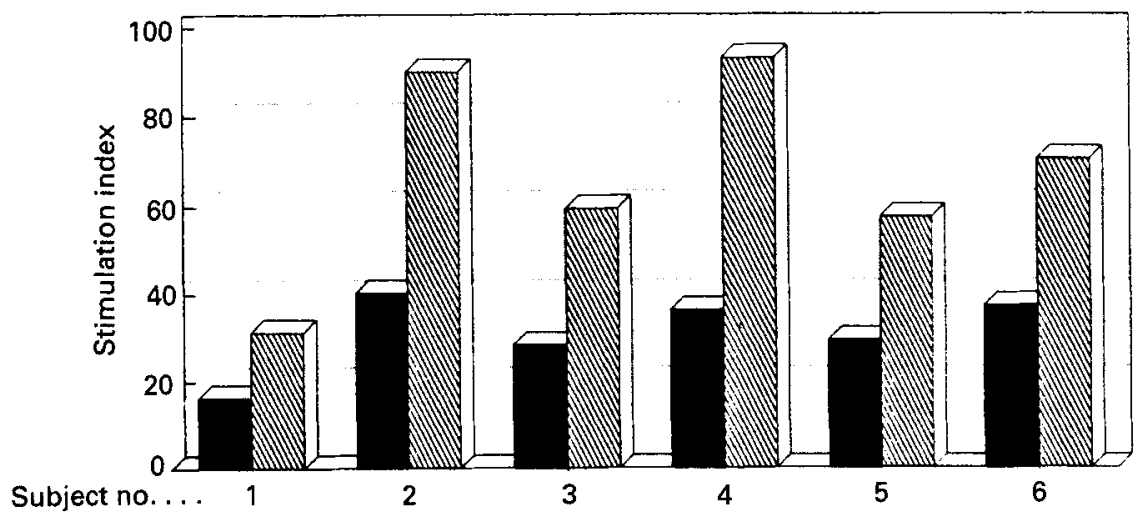

(b) Patients

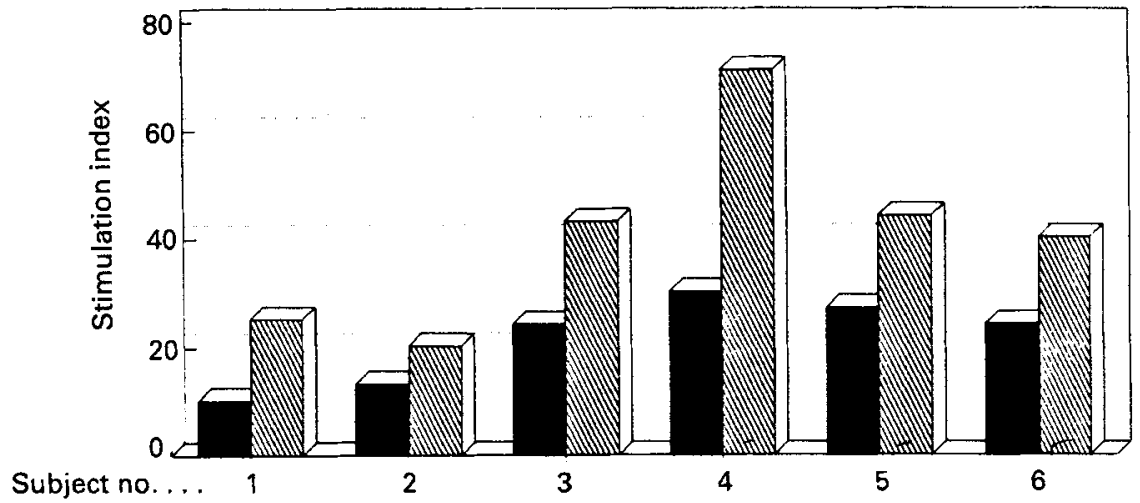

Fig. 3. Stimulation indices of mitogen transformation assays performed with phytohaemagglutinin (PHA) before $(\square)$ and after $(\mathbb{N})$ an oral dose of arginine $(30 \mathrm{~g} / \mathrm{d}$ for $3 \mathrm{~d})$ in (a) volunteers and (b) patients with breast cancer.

The results of the previously mentioned studies are, however, rather non-specific, demonstrating only that the potential of lymphocytes to react to mitogens is increased by arginine. For arginine to be of benefit in the human host-cancer relationship it must have an effect on the effectors of specific anti-cancer immunity. As human cancers frequently do not express transplantation antigens to a high degree, human immune responses are frequently limited to the so-called natural cytotoxicity mediated by natural killer (NK) and lymphokine-activated killer (LAK) cells which are able to lyse target cells in a non-major histocompatibility complex-restricted manner and without previous sensitization to the targets (for review, see Trinchieri, 1989). The next phase of this study was, therefore, to determine the effects of arginine on human NK and LAK cell cytotoxicity. Lymphocytes were obtained from four volunteers and incubated in a medium (RPMI 1640) enriched with arginine as follows: RPMI $1640+$ fetal calf serum $(10 \mathrm{~g} / \mathrm{l})+$ no added arginine, RPMI $1640+$ fetal calf serum $(10 \mathrm{~g} / \mathrm{l})+3 \mathrm{mmol} / \mathrm{l}$ arginine, RPMI 1640 + fetal calf serum $(10 \mathrm{~g} / \mathrm{l})+6 \mathrm{mmol} / \mathrm{l}$ arginine, RPMI $1640+$ fetal calf serum $(10 \mathrm{~g} / \mathrm{l})+$ $30 \mathrm{mmol} / \mathrm{l}$ arginine. 
(a) Effect of arginine on NK cytotoxicity

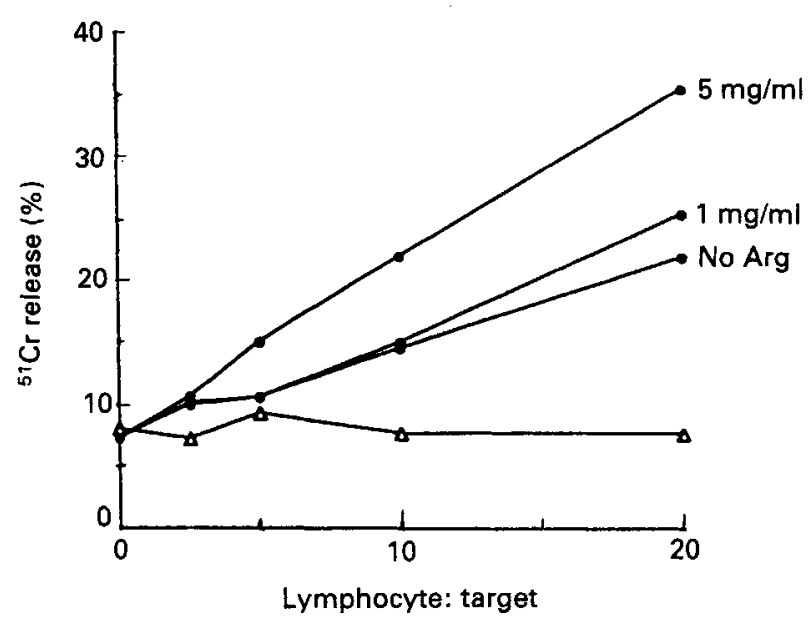

(b) Effect of arginine on LAK cytotoxicity

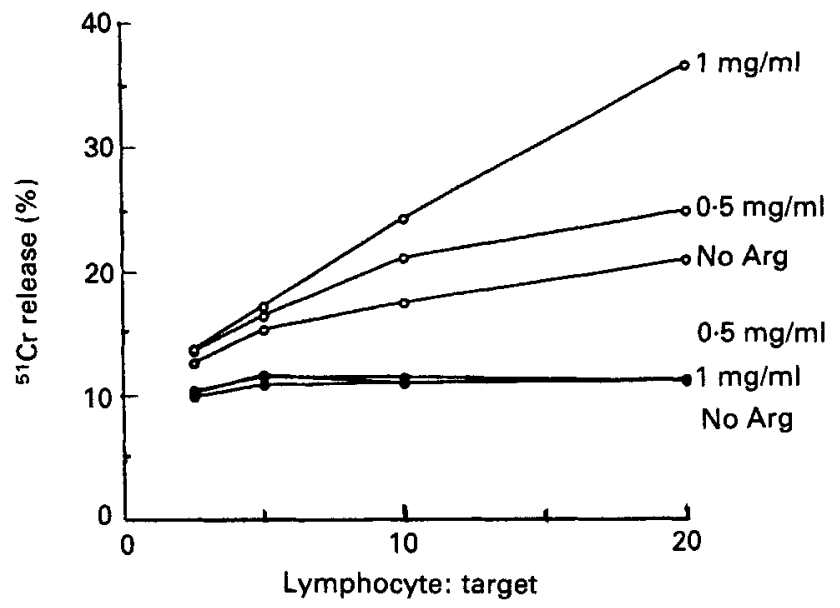

Fig. 4. The effect of arginine on (a) natural killer (NK) and (b) lymphokine-activated killer (LAK) cell cytotoxicity in vitro. $(\triangle)$, Lymphocytes depleted of CD56+ cells; $(O)$, cells pre-incubated with interleukin-2; (O), cells incubated with arginine (Arg) only.

After incubation for $24 \mathrm{~h}$ the lymphocytes were either used as the effector cells against ${ }^{51} \mathrm{Cr}$-labelled K562 lymphomatous cells or further incubated in medium (as described previously) +1000 iu interleukin-2 (IL-2)/ml for $72 \mathrm{~h}$ before being used as the effectors against ${ }^{51} \mathrm{Cr}$-labelled Daudi lymphomatous cells. The results of these killing assays are shown in Fig. 4. It is clear that arginine enhanced NK killing only at high concentrations; however, it appeared to enhance the response to IL-2 and, therefore, LAK cytotoxicity at relatively lower concentrations. 
Table 2. Changes in the expression of CD56 antigen on peripheral blood lymphocytes following $30 \mathrm{~g}$ arginineld for $3 d$

(Values are expressed as absolute nos. of cells $\left(\times 10^{8}\right)$ before and after arginine)

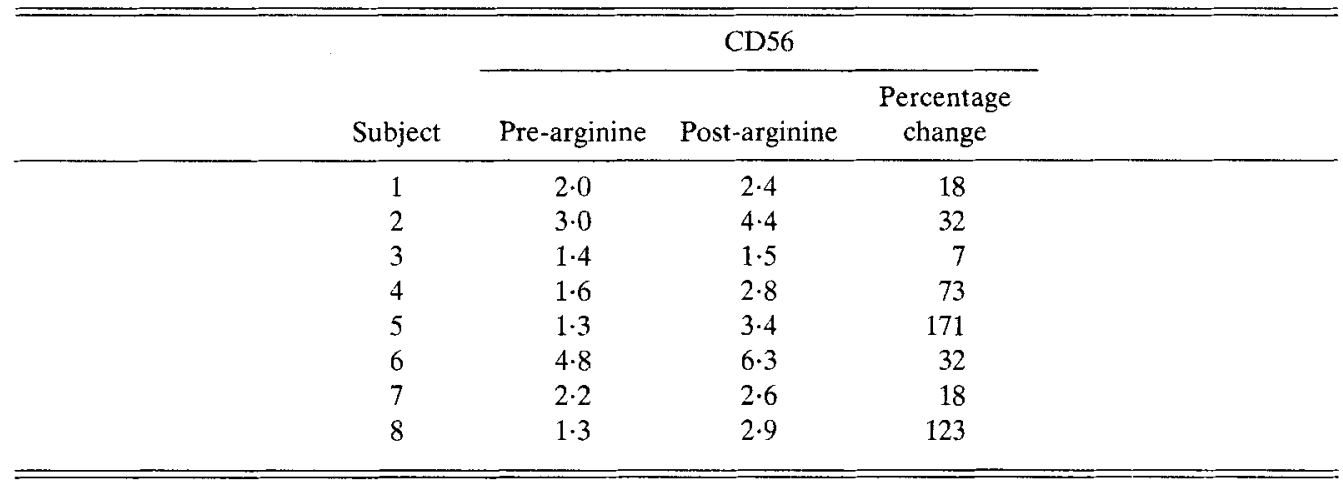

If the lymphocytes were depleted of CD56+ cells before incubation then all cytotoxicity to both K562 and Daudi cells was abolished irrespective of whether arginine was added to the medium or not (Fig. 4). In contrast depletion of CD4+ or CD14+ lymphocytes did not affect the cytotoxicity.

In vivo arginine administration $(30 \mathrm{~g} / \mathrm{d}$ for $3 \mathrm{~d}$ ) to volunteers was found to significantly increase the percentage, and absolute numbers of lymphocytes of the CD56+ subset (Table 2). Furthermore, in thirteen volunteers taking oral arginine, as described previously for $3 \mathrm{~d}$ there was a highly significant increase in the level of NK and LAK cell cytotoxicity in in vitro assays against K562 and Daudi cells respectively (Fig. 5). It is interesting that the two subjects with the highest baseline NK and LAK activity were the two in whom there was little or no response to arginine. In contrast the four individuals with the lowest baseline NK cytotoxicity had the greatest response to arginine; in these subjects the mean increase in cytotoxicity was $195 \%$ whereas for the whole group it was $91 \%$ for NK killing and $58 \%$ for LAK killing.

These experiments were of course conducted using volunteers. The next phase of the study was to determine the response of NK and LAK cells to arginine in cancer patients. A preliminary study was conducted in four patients with relatively advanced breast cancer; in each patient, feeding arginine (30 g/d, for $3 \mathrm{~d}$ ) increased both NK and LAK cell activity. The present study has now been repeated with much larger numbers confirming that arginine enhances NK and LAK cell activity in cancer patients (Brittenden et al. 1993).

\section{THE EFFECTS OF ARGININE ON TUMOUR GROWTH}

The studies described previously have demonstrated that arginine supplementation can stimulate aspects of the host anti-tumour immune response but it is also important to determine the actions of arginine supplementation on tumour growth.

In an attempt to separate the immune stimulatory effects of arginine from the effects on a tumour a nude mouse model was used. Such animals readily accept a variety of tumour xenografts and allow the growth of these to be measured in response to a variety 
(a) NK

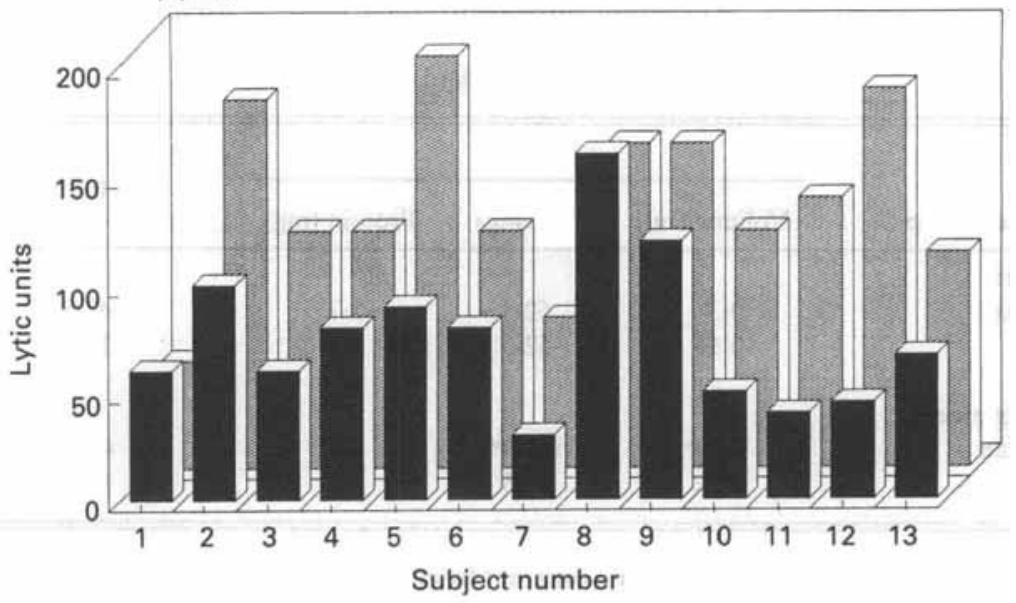

(b) LAK

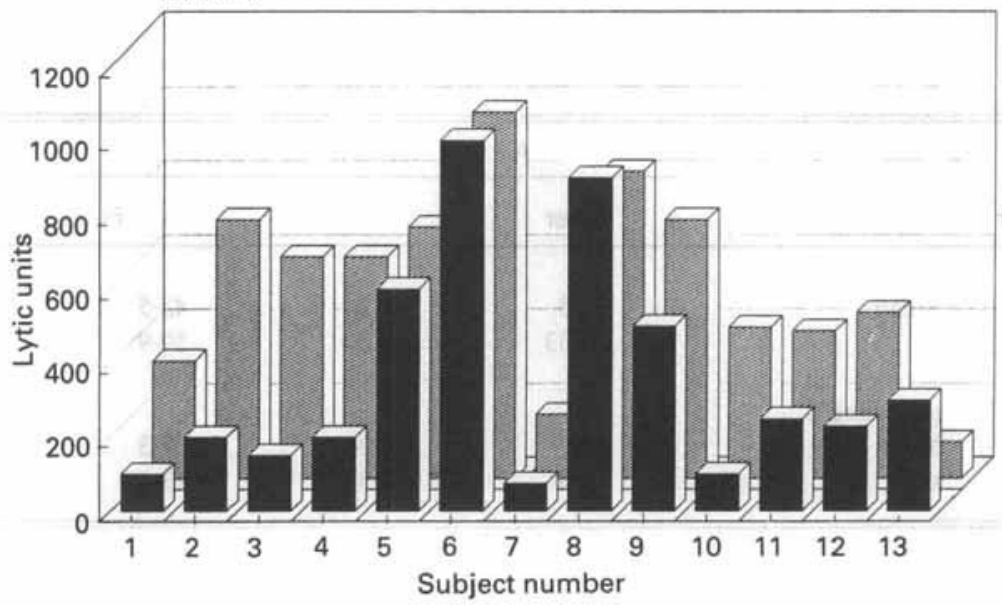

Fig. 5. Natural killer (NK) and lymphokine-activated killer (LAK) cell cytotoxicity in volunteers before ( $\mathbf{\square})$ and after (署) an oral dose of arginine ( $30 \mathrm{~g} / \mathrm{d}$ for $3 \mathrm{~d}$ ).

of treatments. In the present study MIF nu/nu mice were inoculated subcutaneously with $10^{7}$ A549 tumour cells (a cell line originally derived from a human lung cancer). The tumours were allowed to grow for $7 \mathrm{~d}$ before the animals were randomized to a standard diet or an arginine-enriched diet $(8 \mathrm{~g} / \mathrm{l}$ in drinking water). The growth of the tumours was determined weekly with calliper measurements. After $30 \mathrm{~d}$ the animals were killed and the rate of tumour protein synthesis determined following the injection of a flooding dose of $\left[{ }^{3} \mathrm{H}\right]$ phenylalanine (McNurlan et al. 1979). The tumours were also examined histologically, weighed and their protein content determined.

To our surprise it was found that the tumours of the arginine-supplemented animals had the fastest growth rates, weighed more and had higher rates of protein synthesis than the control animals (Table 3 ). It is interesting to note that the rates of muscle and liver protein synthesis were not dissimilar in the two groups of mice (Table 4). 
Table 3. Tumour weight, volume and protein content at $30 \mathrm{~d}$ compared with rates of tumour protein synthesis in MIF nude mice implanted with A549 adenocarcinoma cells

(Mean values and standard deviations)

\begin{tabular}{|c|c|c|c|c|}
\hline \multirow[b]{2}{*}{ Treatment group } & \multicolumn{3}{|c|}{ Tumour } & \multirow{2}{*}{$\begin{array}{c}\text { Fractional rate } \\
\text { of protein } \\
\text { synthesis }(\% / d)\end{array}$} \\
\hline & Volume (ml) & Wt (mg) & Protein (mg) & \\
\hline \multicolumn{5}{|l|}{ Control } \\
\hline Mean & 0.3 & $52 \cdot 5$ & 1.7 & 43.5 \\
\hline SD & $0 \cdot 14$ & $52 \cdot 5$ & $1 \cdot 1$ & $10 \cdot 9$ \\
\hline \multicolumn{5}{|l|}{$8 \mathrm{~g}$ arginine $/ \mathrm{d}$} \\
\hline Mean & $0.72 *$ & $131 \cdot 3^{*}$ & $8.4^{*}$ & $67 \cdot 3^{*}$ \\
\hline $\mathrm{SD}$ & 0.22 & $83 \cdot 5$ & 3.5 & $13 \cdot 1$ \\
\hline
\end{tabular}

Mean values were significantly different from those for controls: ${ }^{*} P<0 \cdot 05$.

Table 4. Rates of liver, muscle and tumour protein synthesis in athymic nude mice implanted with A549 adenocarcinoma cells

(Mean values and standard deviations)

\begin{tabular}{cccc}
\hline \hline & \multicolumn{2}{c}{ Rates of protein synthesis (\%/d) } \\
\cline { 2 - 4 } Treatment group & Liver & Muscle & Tumour \\
\hline Control & & & \\
Mean & 71.3 & 1.24 & 43.5 \\
SD & 3.33 & 0.20 & 10.9 \\
& & & \\
8 garginine/d & & & 67.3 \\
Mean & 82.7 & 1.24 & 13.1 \\
SD & 5.0 & 0.31 & \\
\hline \hline
\end{tabular}

These unexpected results of the animal studies began to cast some doubt on our initial hopes that arginine may be the panacea to nutritional treatment in cancer patients. It was decided, however, to carry on with an experiment to determine the effect of arginine on human tumours in vivo. Women with localized breast cancer were recruited into the study and randomized into two groups: group 1 received arginine supplements $(30 \mathrm{~g} / \mathrm{d}$ for $3 \mathrm{~d}$ ) in addition to a standard diet, group 2 received a standard hospital diet. In both groups the rate of tumour protein synthesis was measured at the time of surgery using a 'flooding' dose technique with $\left[1{ }^{13} \mathrm{C}\right]$ leucine $(4 \mathrm{~g} / 70 \mathrm{~kg}$ body weight, 20 atoms \% enrichment). The excised tumours were examined histologically and, in addition to the standard assessments of mitotic index, cellularity and tumour type, the tumours were also labelled with the monoclonal antibody Ki67. This antibody has been shown to recognize a poorly characterized nuclear antigen expressed on actively dividing cells (Gerdes et al. 1984). Ki67 expression has previously been shown to correlate with other assessments of cell proliferation such as in vitro thymidine uptake (Silvestrini et al. 1988; Kamel et al. 1989). 


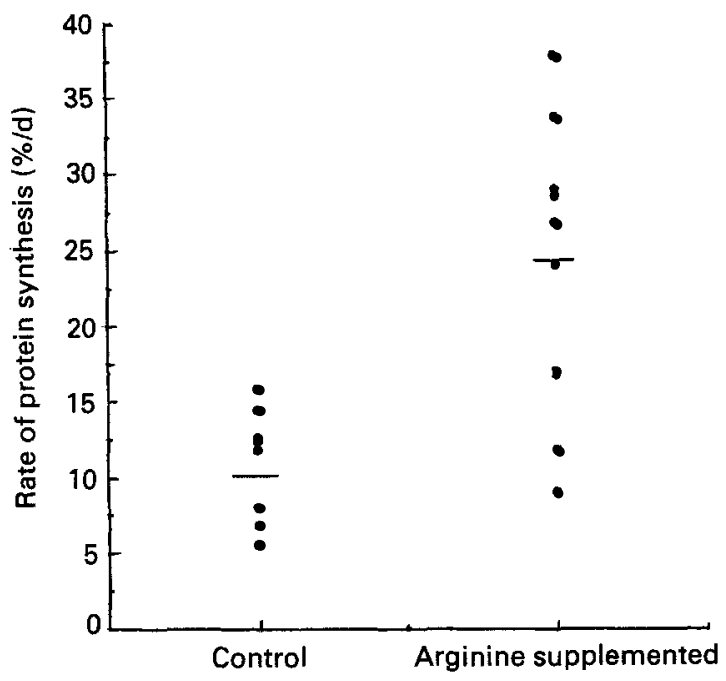

Fig. 6. Rates of tumour protein synthesis in breast cancer patients taking supplemental arginine (30 g/d) compared with controls. (-), Median values.

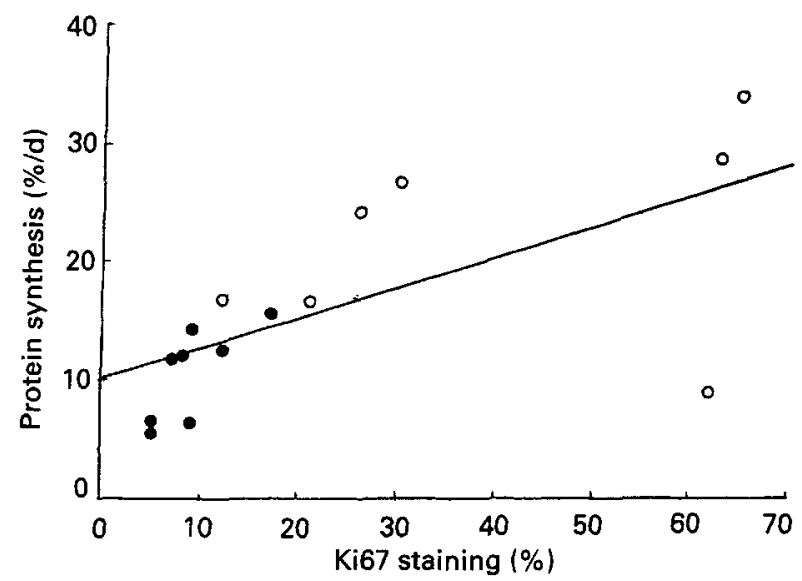

Fig. 7. Correlation between rates of tumour protein synthesis and staining with Ki67 in breast cancers in (O) controls and (O) arginine-supplemented patients.

There was no significant difference between the two groups of patients in terms of age or menopausal status. The mean plasma arginine concentration of the arginine supplemented patients was 230 (range 198-306) $\mu \mathrm{mol} / \mathrm{l}$ compared with 160 (range 132-208) $\mu \mathrm{mol} / \mathrm{l}$ in group 2 . The insulin concentrations were similar in the two groups (Park et al. 1992).

The rates of tumour protein synthesis were significantly higher in the arginine-fed group of patients (Fig. 6). The median rate of protein synthesis was $25 \cdot 6 \% / \mathrm{d}$ in the 
arginine-supplemented group and $10 \% / \mathrm{d}$ in the control group. It is interesting that two patients who had high carcinoma-in situ components to their tumours had the two lowest rates of tumour protein synthesis. Expression of Ki67 was also higher in the argininesupplemented patients compared with the controls and there was a close correlation between the expression of $\mathrm{Ki} 67$ and the fractional rate of tumour protein synthesis $(r 0.78, P<0.001$; Fig. 7 ). However, despite this close correlation one tumour was distant from the others on the scatter plot, with a rate of protein synthesis of $9 \% / \mathrm{d}$ but a Ki67 expression on $62 \%$ of its cells. This tumour was one of the two which had a prominent carcinoma-in situ component and, therefore, was not typical of the group as a whole. The other tumour with the prominent in situ component was too small to obtain sufficient tissue to allow Ki67 to be assessed.

As discussed previously (Park et al. 1992) there was no correlation between mitotic rates or tumour grade and the fractional rates of tumour protein synthesis, but previous authors have highlighted the difficulties in such measures of tumour proliferation (Silverberg, 1976; Hall \& Levison, 1990). Ki67 expression is thought to represent the proportion of the tumour within the growth cycle (Gerdes et al. 1984). Therefore, the present findings of a correlation between tumour protein synthesis and Ki67 expression, and a stimulation of both in breast cancers by arginine supplementation, would appear to indicate a stimulation of tumour growth by arginine.

Although L-arginine supplementation in patients with breast cancer did appear to stimulate their tumours it also stimulated the cells of the reticular endothelial system. Indeed, the measured rate of tumour protein synthesis in these experiments represents the summation of the rates of synthesis in many different cell types including: cancer cells, lymphocytes, fibroblasts and macrophages. This begs the question, rather like the colorectal tumours and total parenteral nutrition, as to which cells are responsible for the apparent stimulation of the tumours (Heys et al. 1991). Obviously if the rate of tumour protein synthesis and expression of $\mathrm{Ki} 67$ was increased due to a stimulation of tumour-infiltrating lymphocytes this would have a totally different significance from a stimulation of the cancer cells themselves. It is not possible to determine from the sections of tumours looked at in the previously mentioned study which cells were expressing Ki67. An approach, such as was used with the colorectal tumours, in which the tumours were enzymically digested and the tumour cells isolated for in vitro studies could not be used to determine the effects of arginine on different cell populations in vivo. Therefore, tumours from a further two patients given arginine were studied immunohistochemically. The rates of tumour protein synthesis in these two patients were determined as described previously, and found to be 15 and $24 \% / \mathrm{d}$ respectively. In each case cryostat sections of the tumours were obtained and stained for Ki67 and either CD2 + lymphocytes or macrophages. Lymphocytes expressing the CD2 surface antigen include $\mathrm{T}$ cells and NK/LAK cytotoxic cells. In the tumour of the first patient 2591 cells were counted in ten high-power microscope fields; $12 \%$ of these cells were Ki67 positive, $20 \%$ were $\mathrm{CD} 2$ positive and $50 \%$ were macrophages. Only three CD2 positive cells were also positive for Ki67 and three macrophages were also positive for Ki67. In the second tumour 3433 cells were counted; $26 \%$ were Ki67 positive, $24 \%$ were CD2 positive and $30 \%$ were macrophages. Only $2 \%$ of Ki67-positive cells were either macrophages or CD2-positive lymphocytes. These results would appear to show that the observed stimulatory effects of arginine are due to direct effects on the tumour cells themselves. 


\section{ARGININE AND HUMAN TUMOURS}

The results of the various studies described previously have led to the conclusion that arginine supplementation in man results in both a stimulation of the host defences and also the tumour cells themselves. These effects may occur in animals but because of the relative immunogenicity of most of these tumours the immune stimulatory effects may outweigh the tumour-enhancing effects resulting in reduced tumour growth and spread (Pryme, 1977; Tachibana et al. 1985; Reynolds et al. 1988a). In a poorly immunogenic mouse tumour, arginine actually enhanced tumour growth (Reynolds et al. 1988b). This is perhaps more analogous with the situation in man, where it would appear that the tumour-enhancing effects of arginine outweigh the immune stimulatory effects. Until the mechanisms for these actions of arginine are determined and, it is possible to separate the effects on tumours and the immune system the use of arginine supplementation in cancer patients must be viewed with some caution. These studies do show, however, that a single amino acid may have profound effects on human tumours and points the way to nutritional/pharmacological manipulation of tumours in man.

The author is most grateful to his colleagues with whom he collaborated during the studies described in this lecture, in particular Professor Eremin from the Department of Surgery, University of Aberdeen and Dr Peter Garlick from the Rowett Research Institute, Aberdeen. Funding for the projects was obtained from the Jean V. Baxter Fellowship awarded by the Scottish Hospitals Endowments Research Trust, the Clinical Metabolism and Nutritional Support Group Research Fellowship and grants from the Royal College of Surgeons of Edinburgh and Grampian Health Board.

\section{REFERENCES}

Baccino, F. M., Tessitore, L. \& Bonelli, G. (1984). Control of protein degradation and growth in normal and neoplastic cells. Toxicology and Pathology 12, 281-287.

Barbul, A. (1986). Arginine biochemistry, physiology and therapeutic implications. Journal of Parenteral and Enteral Nutrition 10, 227-238.

Barbul, A., Rettura, G. \& Levenson, S. M. (1977). Arginine: thymotropic and wound promoting agent. Surgical Forum 28, 101-103.

Barbul, A., Sisto, D. A., Wasserkrug, H. L. \& Efron, G. (1981). Arginine stimulates lymphocyte immune response in healthy human beings. Surgery 90, 244-251.

Barbul, A., Wasserkrug, H. L. \& Seifter, E. (1980). Immunostimulatory effects of arginine in normal and injured rats. Journal of Surgical Research 29, 228-235.

Brittenden, J., Park, K. G. M., Hayes, P. D., Ashby, J. A., Heys, S. D. \& Eremin, O. (1992). The effect of arginine in cancer patients and healthy volunteers. British Journal of Surgery 79, 442.

Brittenden, J., Park, K. G. M., Heys, S. D., Ross, C., Ashby, J. A., Ah-See, A. K. \& Eremin, O. (1993). L-Arginine stimulates host defences in patients with breast cancer. Surgery (In the Press).

Conti, S., West, J. P. \& Fitzpatrick, H. F. (1977). Mortality and morbidity after esophàgo gastrectomy for cancer of the esophagus and cardia. American Surgery 43, 92-96.

Daly, J. M., Reynolds, J. V., Sigal, R. K., Shou, J. \& Liberman, M. D. (1990). Effect of dietary protein and amino acids on immune function. Critical Care Medicine 18, S86-S93.

Detsky, A. S., Baker, J. P., O'Rourke, K., Johnston, N., Whitwell, J., Mendelson, R. A. \& Jeejeebhoy, K. N. (1987). Predicting nutrition associated complications for patients undergoing gastrointestinal surgery. Journal of Parenteral and Enteral Nutrition 11, 440-446.

Douglas, R. G. \& Shaw, J. H. (1990). Metabolic effects of cancer. British Journal of Surgery 77, 246-254.

Gerdes, J., Lemke, H., Baisch, H., Wacker, H. H., Schwab, U. \& Stein, H. (1984). Cell cycle analysis of a cell proliferation associated human nuclear antigen defined by the monoclonal antibody Ki-67. Journal of Immunology 133, 1710-1716. 
Hall, P. A. \& Levison, D. A. (1990). Review: assessment of cell proliferation in histological material. Journal of Clinical Pathology 43, 184-192.

Heatly, R. V., Williams, R. H. P. \& Lewis, M. H. (1979). Preoperative intravenous feeding: a controlled trial. Postgraduate Medical Journal 55, 541-545.

Heys, S. D., Park, K. G. M., McNurlan, M. A., Milne, E., Eremin, O., Wernerman, J., Keenan, R. A. \& Garlick, P. J. (1991). Stimulation of protein synthesis in human tumours by parenteral nutrition: evidence for modulation of tumour growth. British Journal of Surgery 78, 483-487.

Hoiter, A. R. \& Fisher, J. E. (1977). The effects of perioperative hyperalimentation on complications in patients with carcinoma and weight loss. Journal of Surgical Research 23, 31-34.

Jensen, S. (1985). Clinical effects of enteral and parenteral nutrition preceding surgery. Medical Oncology and Tumour Pharmacotherapy 2, 225-229.

Kamel, O. W., Franklin, W. A., Ringus, J. C. \& Meyer, J. S. (1989). Thymidine labelling and Ki-67 growth fraction in lesions of the breast. American Journal of Pathology 143, 107-113.

King, W. W. K., Boelhouwer, R. U. \& Kingsnorth, A. N. (1985). Total parenteral nutrition with and without fat as substrate for growth of rats and transplanted hepatocarcinoma. Journal of Parenteral and Enteral Nutrition 9, 422-427.

Kuppner, M., Wilkinson, S., Casson, E. \& Eremin, O. (1987). In vitro generation of tumour-specific lymphocyte reactivity to colonic carcinoma cells comparison with normal colonic mucosa cells. Cancer Immunology and Immunotherapy 25, 209-214.

Lockwood, T. D., Minassian, I. A. \& Roux, L. (1982). Protein turnover and proliferation turnover kinetics associated with elevation of $3 \mathrm{~T}_{3}$-cell acid protease activity and cessation of net protein gain. Biochemical Journal 206, 239-249.

McNurlan, M. A. \& Clemens, M. J. (1986). Inhibition of cell proliferation by interferons. Biochemical Journal 237, 871-876.

MeNurlan, M. A., Tomkins, A. M. \& Garlick, P. J. (1979). The effect of starvation on the rate of protein synthesis in rat liver and small intestine. Biochemical Journal 178, 373-379.

Moghissi, K., Hornshaw, J., Teasdale, P. R. \& Dawes, E. A. (1977). Parenteral nutrition in carcinoma of the oesophagus treated by sugar: nitrogen balance and clinical studies. British Journal of Surgery 64, 125-128.

Muller, J. M., Brenner, U., Dienst, C. \& Pichlmaier, H. (1982). Preoperative parenteral feeding in patients with gastrointestinal carcinoma. Lançet i, 68-71.

Muller, J. M., Keller, H. W., Brenner, U., Walter, M. \& Holzmuller, W. (1986). Indications and effects of preoperative parenteral nutrition. World Journal of Surgery 10, 53-63.

Nixon, D. W., Lawson, D. H., Kutner, M., Ansley, J., Scharz, M., Heymsfield, S., Chawla, R., Cartwright, T. H. \& Rudman, D. (1981). Hyperalimentation of the cancer patient with protein calorie undernutrition. Cancer Research 41, 2038-2045.

Park, K. G. M., Heys, S. D., Blessing, K., Kelly, P., McNurlan, M. A., Eremin, O. \& Garlick, P. J. (1992). Stimulation of human breast cancers by dietary L-arginine. Clinical Science 82, 413-417.

Popp, M. B., Wagner, S. C. \& Brito, O. J. (1983). Host and tumour responses to increasing levels of nutritional support. Surgery 94, 300-308.

Pryme, I. F. (1977). The failure of growth of a mouse myeloma during the course of administration of L-arginine hydrochloride. Cancer Letters 1, 177-182.

Reynolds, J. V.. Daly, J. M., Zhang, S., Evantash, E., Shou, J., Sigal, R. \& Ziegler, M. M. (1988a). Immunomodulatory mechanisms of arginine. Surgery 104, 142-151.

Reynolds, J. V., Thom, A. K., Zhang, S. M., Ziegler, M. M., Naji, A. \& Daly, J. M. (1988b). Arginine protein malnutrition and cancer. Journal of Surgical Research 45, 513-522.

Sako, K., Lore, J. M., Kaufman. S., Razack, M. S., Bakamijiam, V. \& Reese, P. (1981). Parenteral hyperalimentation in surgical patients with head and neck cancer: a randomized study. Journal of Surgical Oncology 16, 391-402.

Siato, H., Trocki, O., Wang, S., Gonce, S. J., Joffe, S. N. \& Alexander, J. W. (1987). Metabolic and immune effects of dietary arginine supplementation after burn. Archives of Surgery 122, 784-789.

Silverberg. S. G. (1976). Reproducibility of the mitosis count in the histologic diagnosis of smooth muscle tumours of the uterus. Human Pathology 7, 451-454.

Silvestrini, R., Costa, A., Vereroni, S., Del Bino, G. \& Perici, P. (1988). Comparative analysis of different approaches to investigate cell kinetics. Cell Tissue Research 21, 123-131.

Studley, H. O. (1936). Percentage of weight loss a basic indicator of surgical risk. Journal of the American Medical Association 106, 458-460. 
Tachibana, K., Mukai, K., Hiraoka, I., Moriguchi, S., Takama, S. \& Kishino, Y. (1985). Evaluation of the effect of arginine enriched amino acid solution on tumour growth. Journal of Parenteral and Enteral Nutrition 9, 428-434.

Thompson, B. R., Julian, T. B. \& Stremple, J. F. (1981). Preoperative total parenteral nutrition in patients with gastrointestinal cancer. Journal of Surgical Research 30, 497-500.

Torosian, M. H., Tsou, K. C. \& Daly, J. M. (1984). Alteration of tumour cell kinetics by pulse total parenteral nutrition: potential therapeutic implications. Cancer 53, 1409-1415.

Trinchieri, G. (1989). Biology of natural killer cells. Advances in Immunology 47, 187-376.

Veterans Affairs Total Parenteral Nutrition Cooperative Study Group (1991). Perioperative total parenteral nutrition in surgical patients. New England Journal of Medicine 325, 525-532.

Von Meyenfeldt, M. F., Fredrix, E. W. H. M., Van der Aalst, A. C. M. J. \& Soeters, P. B. (1988). The aetiology and management of weight loss in cancer patients. Bailliere's Clinical Gastroenterology 2 , 869-885.

Wan, J. M. F., Haw, M. P. \& Blackburn, G. L. (1989). Nutrition, immune function and inflammation: an overview. Proceedings of the Nutrition Society 48, 315-335.

Windsor, J. A. \& Hill, G. L. (1988). Weight loss with physiological impairment. An indicator of surgical risk. Annals of Surgery 207, 290-296. 